\title{
INSECTICIDAL POTENCY OF NATIVE ENTOMOPATHOGENIC FUNGI ISOLATES AGAINST THE Galleria mellonella (LEPIDOPTERA: PYRALIDAE) AND Spodoptera littoralis (LEPIDOPTERA: NOCTUIDAE) Larvae.
}

Aamer, H. A. H.; F. A. Kassem; Soad M. Ahmed and E. A. M Abdallah

Department of Pesticide chemistry and Technology, Faculty of Agriculture, Alexandria University

\begin{abstract}
The entomopathogenic fungi (EPF) have received considerable attention for their potential use in biological control of insect pests. In this study, twenty four native strains were isolated from Alexandria governorate. This isolates were identified as 21 Beauveria bassiana (Ascomycota: Hypocreales) isolates and three isolates of Metarhizium anisopliae (Ascomycota: Hypocreales). Isolates were preliminary evaluated at $1 \times 108$ conidia $\mathrm{ml}-1$ under laboratory conditions against $3^{\text {rd }}$ instar larvae of Spodoptera littoralis and $4^{\text {th }}$ instar of G. mellonella larvae. In addition, concentration-mortality relationship was conducted for selected three native $B$. bassiana isolates compared with two exotic isolates $B$. bassiana (Bio-power) and $M$. anisopliae (Bio-magic). The result revealed that the larvae of $G$. mellonella were more sensitive than Spodoptera littoralis to all EPF isolates with $\mathrm{LT}_{50}$ range (6.2811.21days) and (7.81-13.28 days) respectively. The results indicated a significance difference $(\alpha=0.05)$ for 13 native EPF isolates in their speed of kill (LT50) toward G. mellonella than $\mathrm{S}$. littoralis. In addition, the concentration-mortality relationship assay showed that larvae mortality increase in a linear relationship with conidia concentration and the $\mathrm{Bb}-\mathrm{Mo} 12$ a native isolate causing higher mortality percentage in both tested larvae, while Bio-power caused the lower mortality percentage in both larvae at higher tested concentration. The result show that Bb-Mo12 isolate have a lower $\mathrm{LC}_{50} 1.3 \times 10^{6}$ and $1.1 \times 10^{7}$ conidia $\mathrm{ml}-1$ toward $\mathrm{G}$. mellonella and $\mathrm{S}$. littoralis larvae respectively. from these results, we could conclude that there are a variation between native EPF isolates in their virulence toward insect pest and some isolates have a promising potential for use as biocontrol agents in the field of insect control.

Keyword: Native, virulence, Galleria mellonella, Spodoptera littoralis, entomopathogenic fungi, biological control.
\end{abstract}

\section{INTRODUCTION}

The cotton leafworm Spodoptera littoralis (Boisd.) (Lepidoptera: Noctuidae) is one of the important widespread pests that cause great damage to cotton plants as well as other field and vegetable crops in Egypt and subtropical region in the world (Willcocks and Bahgat, 1937; Moussa, et.al., 1960; Bishara, 1954). It have a wide range of host plant subject to 27 plant species belonging to 16 families around the year (Salama, et al., 1971; Anderson et al., 2001). It cause a significance damage and loss in the yield of several economically crops (Carter, 1984)

The products of beehives such as wax have a wide usage in pharmaceutical industry, health care, dentistry and cosmetics in addition to their nutritional value, which limit the usage of pesticide in the control of 
insect pests inside the beehives. The greater wax moth Galleria mellonella L. (Lepidoptera: Pyralidae) considered a serious pest of beehives which cause a damage through feeding upon pollen and tunnelling through the combs (Jackman and Drees 1998; Chandel et al. 2003). Wax moth damage only during their larval stage. The moth is widely distributed throughout the world, causing serious problems in temperate, tropical and subtropical beekeeping regions, where the warm temperature favour the rapid development of the moth (Spangler 1989).

The rapid increase in human population with changes in dietary habits towards high quality food required is thought to cause more than double demands for crop production. However, the climate changes will add to the crisis (Tubiello et al., 2007). as agricultural production intensified over the past few decades, producers became more dependent on agrochemicals and the chemical pesticides become the main agents used in crop protection,

The conventional chemical pesticides have although enhanced the food production, but have also adversely affected the environment and non target organisms. In addition Chemical pesticides are continuously accumulating in the environment, harming the ecosystem, causing pollution,(Gerhardson 2002).

There are increasing pressure to move towards more environmentally friendly biological control systems (Hall and Papierok, 1982; Moore and Prior, 1993). A promising strategy with good potential to control insect pests in addition to minimize adverse effects of chemical insecticides is the use of entomopathogenic microbial agents such as fungi. Mycoinsecticides are safer than chemical insecticides in that they are selective, biodegradable, can be incorporated into IPM programs, and by remaining in the environment as successive generations they may give extended control (Moore and Prior, 1993). There are more than 800 species of fungi belong to more than 90 genera that are pathogenic to insects (Thackar, 2002). The Metarhizium and Beauveria being the best known genera as they have a wide geographical distribution and host range (Hall and Papierok, 1982; McCoy et al., 1988). Fungal biological control agents have demonstrated efficacy against a wide range of insect pests including Spodoptera species and Galleria mellonella (Purwar and Sachan, 2005; Lin et al., 2007; Shairra and Gehan 2014; Gabarty et al, 2014 and Hussein, et al., 2012).

The objectives of this study were to assess the insecticidal activity of native isolates of entomopathogenic fungi against $3^{\text {rd }}$ instar larvae of $S$. littoralis and $4^{\text {th }}$ istar larvae of $G$. mellonella in addition to comparative study of selected native and exotic isolates against the same tested larvae.

\section{MATERIALS AND METHODS}

\section{Rearing of tested insects}

A susceptible Egyptian cotton leafworm, S. littoralis, strain was obtained from the biological control laboratory, department of economic entomology faculty of agriculture, Alexandria university. The colony was reared under laboratory conditions on castor oil leaves at $26^{\circ} \mathrm{C} \pm 2,65 \pm 5 \mathrm{RH}$ (El-Defrawi et al., 1964). 
The greater wax moth, G. melonella (L.) larval were obtained from the infested hives and reared in the laboratory at temperature of $28 \pm 2^{\circ} \mathrm{C}$ using the following artificial diet composition: wheat bran, $100 \mathrm{~g}$; wheat flour, $100 \mathrm{~g}$; cornmeal, $200 \mathrm{~g}$; milk powder 100g; dried yeast, $50 \mathrm{~g}$; glycerin, $175 \mathrm{ml}$; and honey, $175 \mathrm{ml}$. (PDBC, 2007)

Entomopathogenic fungi isolates.

Twenty-four native isolates of EPF used in this study. Three of them belong to Metarhizium anisopliae and twenty-one isolates are $B$. bassiana, all isolates were isolated by the insect-baiting technique (Zimmermann, 1986) from soil samples collected during 2012-2013 from Alexandria governorate in Egypt. The identification of fungal isolates based on mycelium growth on the insect and after isolation on media by spore morphology and colour (Samson et al. 1988 and Humber 1997)

From the fungal species, local district name the soil sample were collected, and from positive sample sequence number. The name code for isolates of EPF was designated, according to Montaza district (Mo), Borg elarab district (Bo), Amria district (Am) and eastern district (Ea). Abbreviate for fungal species indication $B$. bassiana $(\mathrm{Bb}) M$. anisopliae (Ma), and sample number (1,2,3); thus isolates were labeled Bb-Mo1, Bb-Mo2, Bb-Bo3, MaAm1..etc.

Two entomopathogenic fungi isolates used as exotic isolates for comparative study, M. anisopliae (Bio-magic) and B. bassiana (Bio-power) available commercially from $\mathrm{T}$. Stanes Company limited, India.

\section{Preparation of fungal inoculum.}

The isolates was grown on potato dextrose agar medium supplemented with $1 \%$ yeast extract (PDAY) in petri dishes $(90 \mathrm{~mm})$ in the dark at $28 \pm 1{ }^{\circ} \mathrm{C}$ for 14 days. The conidia for each fungal isolates was harvested by scraping from the surface of plates with a sterile scalpel, and suspended in a sterile aqueous solution of $0.05 \%$ Tween 80 . The suspension was homogenized by shaken vigorously using a vortex mixer and filtered through sterile muslin to remove mycelia and debris. The conidia concentrations was quantified microscopically using a hemocytometer. The dilutions were made with the $0.05 \%$ (v/v) Tween 80 solution. To prevent germination of conidia before use, the suspensions was placed overnight in a refrigerator at $4{ }^{\circ} \mathrm{C}$. The fungal isolates were used in assay after not more than two subcultures on PDAY to avoid possible loss of virulence associated with continuous culturing (Hajek et al. 1990)

Virulence assays.

The $3^{\text {rd }}$ instar larvae of $S$. littoralis and the $4^{\text {th }}$ instar larvae of $G$. mellonella were used in the experiment. A batch of ten larvae had been used for each fungal isolates for each larvae, three replicates was maintained for each fungal isolate. For inoculation, each group of larvae were sprayed by 5 $\mathrm{ml}$ of conidial suspension at $10^{8}$ conidia $\mathrm{ml}^{-1}$ in the preliminary bioassay for native isolates and the concentrations $10^{6}, 10^{7}, 10^{8}$ and $10^{9}$ conidia ml for concentration-mortality relationship study, using a hand atomizer for each fungal isolates. The control larvae received a spray of $0.05 \%$ tween 80 solution in distilled water, after air-drying, each group was placed in a 
sterilized moist chamber consisting of a petri dish lined with wet filter paper. The experiments conducted at laboratory condition $27 \pm 2^{\circ} \mathrm{C}$ and $75 \pm 10$ relative humidity. Mortality of larvae was assessed daily up to ten days after inoculation.

\section{Statistical analysis}

Time- mortality and concentration-mortality data was performed using probit analysis and calculate regression lines slope and $\mathrm{LT}_{50}$ (median lethal time) or $\mathrm{LC}_{50}$ (median lethal concentration) values were considered significantly different if the $95 \%$ confidence limits did not overlap. To assess the differences in insect mortality percentage among $S$. littoralis and $G$. mellonella larvae for each tested native and exotic EPF isolates, the percent mortality were corrected according to Abbott's formula (Abbott, 1925), and subjected to arcsine square root transformation to increase the homogeneity of variance and normality. Then the data subjected to statistical analysis of variance (ANOVA) using SAS software version 9.0 (SAS Institute, Cary, NC 2004). Means was separated using LSD test and differences at $P \leq 0.05$ were considered significant.

To assess the combined effect of Host larvae species, EPF isolates and EPF concentration on the Corrected cumulative mortality percentage, a fully randomised factorial design was used. The main effect of each factor and their interaction was analysed using the general linear model (GLM) procedure available within the SAS statistical software 9.0 (SAS Institute Inc., 2004), the data used for analysis was arcsine transformed.

\section{RESULTS}

From 1100 soil samples collected from different district in Alexandria city, Egypt about $2.18 \%$ of the sample were positive for the presence of entomopathogenic fungi, 21 isolates of $B$. bassiana and 3 isolates of $M$. anisopliae were isolated on potato dextrose agar + yeast extract (PDAY).

Data present in Table (1) indicate that, both tested insect larvae $S$. littoralis and $G$. mellonella were susceptible to all native isolates of entomopathogenic fungi. There are 13 isolates have a significance difference $(P<0.05)$ in their virulence toward the tested larvae with high speed of kill (low $\mathrm{LT}_{50}$ ) against $\mathrm{G}$. mellonella in comparing with $S$. littoralis larvae these isolates are Bb-Mo1, Bb-Mo21, Bb-Ea6, Bb-Ea7, Bb-Ea11, Bb-Am4, Bb-Am8, Bb-Mo17, Bb-Am20, Ma-Am1, Bb-

For the native $M$. anisopliae isolates we can observe that Ma-Am1 isolate have a significance low $\mathrm{LT}_{50}(\mathrm{P}<0.05)$ in compare with Ma-Bo2 and Ma-Bo3 against $G$. mellonella larvae while no significance difference observed in their $\mathrm{LT}_{50}$ value toward $\mathrm{S}$. littoralis larvae. 
Table (1): $\mathrm{LT}_{50}$ and their $95 \%$ confidence limit, slope $\pm \mathrm{SE}$ and $X^{2}$ for 24 native EPF isolates on two lepidopteron larvae $S$. littoralis and G. mellonella.

\begin{tabular}{|c|c|c|c|c|c|c|c|c|}
\hline \multirow[b]{2}{*}{$\begin{array}{l}\text { Fungi } \\
\text { isolate }\end{array}$} & \multicolumn{4}{|c|}{ G. mellonella } & \multicolumn{4}{|c|}{ S. littoralis } \\
\hline & \begin{tabular}{|c|}
$\mathbf{L T}_{50}$ \\
(day)
\end{tabular} & \begin{tabular}{|l} 
Confidence \\
limit (95\%)
\end{tabular} & $\begin{array}{l}\text { Slope } \\
\pm \text { SE }\end{array}$ & $x^{2}$ & $\begin{array}{l}\mathrm{LT}_{50} \\
\text { (day) }\end{array}$ & \begin{tabular}{|l} 
Confidence \\
limit (95\%)
\end{tabular} & $\begin{array}{l}\text { Slope } \\
\pm \text { SE }\end{array}$ & $x^{2}$ \\
\hline Bb-Mo1 & \begin{tabular}{|l|}
7.67 \\
\end{tabular} & $6.98-8.62$ & $4.38 \pm 0.64$ & 1.24 & 11.24 & $9.57-16.13$ & $4.02 \pm 0.9$ & 0.39 \\
\hline Bb-Mo2 & 11.21 & $9.19-19.18$ & $2.93 \pm 0.78$ & 0.34 & 12.74 & $10.41-21.77$ & $3.91 \pm 0.98$ & 0.51 \\
\hline Bb-Mo12 & 6.60 & $6.06-7.16$ & $5.37 \pm 0.78$ & 3.1 & 7.81 & $7.141-8.749$ & $4.73 \pm 0.78$ & 0.35 \\
\hline Bb-Mo13 & 10.07 & $8.72-13.54$ & $3.67 \pm 0.81$ & 1.49 & 11.19 & $9.50-16.24$ & $3.85 \pm 0.88$ & 0.33 \\
\hline Bb-Mo15 & 8.09 & $7.38-9.15$ & $4.68 \pm 0.79$ & 0.76 & 9.75 & $8.7-13.02$ & $4.62 \pm 0.89$ & 0.13 \\
\hline Bb-Mo17 & 6.29 & $5.8-6.86$ & $5.47 \pm 0.74$ & 1.73 & 10.95 & $9.14-17.14$ & $3.18 \pm 0.79$ & 0.41 \\
\hline Bb-Mo19 & 9.01 & $8.22-10.39$ & $5.24 \pm 0.9$ & 0.11 & 10.71 & $9.11-15.38$ & $3.57 \pm 0.82$ & 0.29 \\
\hline Bb-Morl & 7.07 & $6.43-7.88$ & $4.23 \pm 0.61$ & 0.51 & 12.78 & $10.14-25.35$ & $3.09 \pm 0.84$ & 0.14 \\
\hline Bb-Ea6 & 7.94 & $7.28-8.87$ & $4.96 \pm 0.8$ & 0.51 & 12.25 & $10.15-19.63$ & $3.95 \pm 0.96$ & 0.94 \\
\hline Bb-Ea7 & 6.28 & $5.77-6.81$ & $5.84 \pm 0.92$ & 2.34 & 11.48 & $9.43-19.01$ & $3.03 \pm 0.79$ & 0.73 \\
\hline Bb-Ea11 & 21 & $6.62-7.92$ & $4.97 \pm 0.77$ & 0.19 & 12.08 & $9.88-20.44$ & $3.41 \pm 0.86$ & 0.44 \\
\hline Bb-Ea14 & 10.42 & $8.88-14.86$ & $3.43 \pm 0.8$ & 0.29 & 10.65 & $9.12-14.94$ & $3.72 \pm 0.84$ & 0.24 \\
\hline Bb-Ea18 & 9.46 & $8.34-11.93$ & $3.88 \pm 0.8$ & 0.59 & 11.75 & $9.82-18.13$ & $3.80 \pm 0.9$ & 0.45 \\
\hline Bb-Am4 & 6.63 & $6.05-7.30$ & $4.40 \pm 0.6$ & 4.42 & 10.01 & $8.75-13.02$ & $3.98 \pm 0.83$ & 0.61 \\
\hline Bb-Am5 & 7.43 & $6.86-8.13$ & $5.38 \pm 0.81$ & 0.18 & 8.20 & $7.52-9.21$ & $5.05 \pm 0.83$ & 0.14 \\
\hline Bb-Am8 & 8.31 & $7.49-9.64$ & $4.09 \pm 0.64$ & 0.14 & 12.13 & $9.87-21.1$ & $3.41 \pm 0.86$ & 0.86 \\
\hline Bb-Am20 & 8.32 & $7.63-9.39$ & $5.07 \pm 0.83$ & 0.51 & 11.81 & $9.78-18.85$ & $3.58 \pm 0.87$ & 0.54 \\
\hline Ma-Am1 & 7.05 & $6.44-7.76$ & $4.75 \pm 0.76$ & 1.82 & 10.58 & $8.97-15.43$ & $3.38 \pm 0.8$ & 0.24 \\
\hline Bb-Bo3 & 8.53 & $7.69-9.98$ & $4.27 \pm 0.79$ & 0.17 & 11.22 & $9.45-16.77$ & $3.62 \pm 0.85$ & 0.63 \\
\hline Bb-Bo9 & 6.79 & $6.22-7.41$ & $5.01 \pm 0.76$ & 0.1 & 13.28 & $10.31-29.88$ & $2.92 \pm 0.84$ & 0.09 \\
\hline Bb-Bo10 & 6.66 & $6.08-7.92$ & $4.97 \pm 0.77$ & 1.0 & 9.61 & $8.33-11.98$ & $4.62 \pm 0.89$ & 0.15 \\
\hline Bb-Bo16 & \begin{tabular}{|l|}
8.05 \\
\end{tabular} & $7.36-9.08$ & $4.78 \pm 0.8$ & 1.17 & 11.31 & $9.29-19.01$ & $3.03 \pm 0.79$ & 0.34 \\
\hline Ma-Bo2 & 9.16 & $7.9-12.46$ & $3.02 \pm 0.73$ & 0.37 & 11.51 & $9.59-18.02$ & $3.51 \pm 0.85$ & 0.71 \\
\hline Ma-Bo3 & 9.67 & $8.42-12.72$ & $3.60 \pm 0.78$ & 1.43 & 11.65 & $9.99-16.55$ & $4.8 \pm 1.08$ & 0.93 \\
\hline
\end{tabular}

$\mathrm{Bo9}, \mathrm{Bb}-\mathrm{Bo} 10$ and $\mathrm{Bb}-\mathrm{B} 016$. This isolates were isolated from different district and location which mean that there are a variation between the isolates from the specific location in their virulence against tested larvae. The most virulent isolates toward G. mellonella larvae was $\mathrm{Bb}-\mathrm{Ea} 7$ with $\mathrm{LT}_{50}$ value 6.28 days while the most virulent isolate against $\mathrm{S}$. littoralis larvae was $\mathrm{Bb}-\mathrm{Mo12}$ with $\mathrm{LT}_{50}$ value 7.81 days. The $\mathrm{LT}_{50}$ range between 6.28 11.21 days for tested isolates against $G$. mellonella while the range of $\mathbf{L T}_{50}$ for the native isolates against $\mathrm{S}$. littoralis were $7.81-13.28$ days. We also can observe that there is no any isolate have a higher virulence toward S. littoralis in compare with $G$. mellonella from the tested isolates.

Data in Table (2) show the cumulative mortality percentage of $S$. littoralis and G. mellonella larvae after treatment with different concentration of selected native and exotic EPF isolates. The data show that mortality percentage was in a linear relationship with conidial concentration, mortality increased as the applied conidia suspension increase in all tested EPF isolates. The higher mortality rate $96.5 \%$ obtained with $\mathrm{Bb}-\mathrm{Mo} 12$ isolate against G. mellonella larvae at 109 conidia $\mathrm{ml}-1$. In 
Table (2): $L C_{50}$ and their $95 \%$ confidence limit, slope \pm SE and $X^{2}$ for native and exotic EPF isolates against two lepidopteron larvae S. littoralis and G. mellonella

\begin{tabular}{|c|c|c|c|c|c|c|c|c|}
\hline \multirow[b]{2}{*}{$\begin{array}{l}\text { Fungi } \\
\text { isolate }\end{array}$} & \multicolumn{4}{|c|}{ G. mellonella } & \multicolumn{4}{|c|}{ S. littoralis } \\
\hline & $\begin{array}{l}\mathrm{LC}_{50} \\
\text { spore } \\
\mathrm{ml}^{-1}\end{array}$ & $\begin{array}{c}\text { Confide } \\
\text { nce limit } \\
(95 \%)\end{array}$ & $\begin{array}{l}\text { Slope } \\
\pm \text { SE }\end{array}$ & $x^{2}$ & $\begin{array}{l}\text { LC }_{50} \\
\text { spore } \\
\text { ml }^{-1}\end{array}$ & \begin{tabular}{|c|} 
Confide \\
nce limit \\
$(95 \%)$
\end{tabular} & $\begin{array}{l}\text { Slope } \\
\pm \text { SE }\end{array}$ & $x^{2}$ \\
\hline $\begin{array}{l}\text { Bb- } \\
\text { Am5 }\end{array}$ & $1.6 \times 10^{7}$ & $\begin{array}{c}6.6 \times 10^{6}- \\
3.7 \times 10^{7}\end{array}$ & $\begin{array}{c}0.76 \pm \\
0.14\end{array}$ & 1.25 & $\begin{array}{c}3.9 x \\
10^{7} \\
\end{array}$ & $\begin{array}{c}1.5 \times 10^{\prime}- \\
1.1 \times 10^{8}\end{array}$ & $\begin{array}{c}0.60 \pm \\
0.12\end{array}$ & 1.75 \\
\hline $\begin{array}{l}\mathrm{Bb}- \\
\text { Bo10 }\end{array}$ & $5.0 \times 10^{6}$ & $\begin{array}{c}1.8 \times 10^{6}- \\
1.1 \times 10^{7}\end{array}$ & $\begin{array}{c}0.79 \pm \\
0.14\end{array}$ & 0.32 & $1.1 \times 10^{8}$ & $\begin{array}{c}4.3 \times 10^{\prime}- \\
3.8 \times 10^{8}\end{array}$ & $\begin{array}{c}0.61 \pm \\
0.12\end{array}$ & $0.67 \mid$ \\
\hline $\begin{array}{l}\mathrm{Bb}- \\
\mathrm{Mo12}\end{array}$ & $1.3 \times 10^{6}$ & $\begin{array}{l}1.5 \times 10^{5}- \\
3.3 \times 10^{6}\end{array}$ & $\begin{array}{c}0.74 \pm \\
0.2\end{array}$ & 0.15 & $\times 10^{7}$ & $\begin{array}{r}2.3 \times 10^{6}- \\
3.4 \times 10^{7}\end{array}$ & $\begin{array}{c}0.48 \pm \\
0.11\end{array}$ & 0.77 \\
\hline $\begin{array}{l}\text { Bio- } \\
\text { power }\end{array}$ & $1.1 \times 10^{8}$ & $\begin{array}{c}2.8 \times 10^{\prime}- \\
1.0 \times 10^{9}\end{array}$ & $\begin{array}{c}0.40 \pm \\
0.11 \\
\end{array}$ & 0.02 & $x 10^{8}$ & $\begin{array}{l}7.1 \times 10^{\prime}- \\
3.2 \times 10^{9}\end{array}$ & $\begin{array}{c}0.43 \pm \\
0.11\end{array}$ & 0.1 \\
\hline $\begin{array}{l}\text { Bio- } \\
\text { magic }\end{array}$ & $1.1 \mathrm{x}$ & $\begin{array}{l}3.1 \times 10^{6} \\
2.9 \times 10^{7}\end{array}$ & $\begin{array}{c}0.57 \pm \\
0.12\end{array}$ & 0.06 & $0^{7}$ & $\begin{array}{c}6.8 \times 10^{6}- \\
8.5 \times 10^{7}\end{array}$ & $\begin{array}{c}0.49 \pm 0 . \\
11\end{array}$ & 0.32 \\
\hline
\end{tabular}

Table (3): Corrected cumulative mortality percentage (mean $\pm S E$ ) for selected native and exotic EPF isolates toward two lepidopteron larvae S. littoralis and G. mellonella

\begin{tabular}{|c|c|c|c|c|c|}
\hline \multirow{2}{*}{\begin{tabular}{|l|}
$\begin{array}{l}\text { Fungi } \\
\text { isolate }\end{array}$ \\
\end{tabular}} & \multirow{2}{*}{ sect host } & \multicolumn{4}{|c|}{$\%$ corrected cumulative mortality (mean $\pm S E$ ) } \\
\hline & & $1 \times 10^{6}$ & $1 \times 10^{7}$ & $1 \times 10^{8}$ & \\
\hline & & & & & \\
\hline & & & & & \\
\hline & & & & $89.8 \varepsilon$ & \\
\hline & & $\begin{array}{l}19.8 \varepsilon \\
13.2\end{array}$ & & $7^{a}$ & 0.4 \\
\hline & & $\begin{array}{l}29.88 \pm 6.67^{\mathrm{a}} \\
23.22 \pm 3.33^{\mathrm{a}}\end{array}$ & $\begin{array}{l}46.55 \pm 5.77^{a} \\
39.88+3.33^{a}\end{array}$ & $\begin{array}{l}69.88 \pm 3.33^{a} \\
63.22 \pm 6.67^{a}\end{array}$ & $\begin{array}{l}83.22 \pm 3.33^{\mathrm{a}} \\
73.22 \pm 3.33^{\mathrm{a}}\end{array}$ \\
\hline
\end{tabular}
significance difference at $P \leq 0.05$

Data in Table (2) show the cumulative mortality percentage of $S$. littoralis and G. mellonella larvae after treatment with different concentration of selected native and exotic EPF isolates. The data show that mortality percentage was in a linear relationship with conidial concentration, mortality increased as the applied conidia suspension increase in all tested EPF isolates. The higher mortality rate $96.5 \%$ obtained with $\mathrm{Bb}-\mathrm{Mo} 12$ isolate 
against $\mathrm{G}$. mellonella larvae at $10^{9}$ conidia $\mathrm{ml}^{-1}$. In addition to, we can observe that there are a significance difference in the mortality percentage between $S$. littoralis and $G$. mellonella larvae (at $p<0.05$ ) within isolate Bb-Bo10 at all tested concentration while, in Bb-Mo12 isolate the significance difference in mortality percentage in both tested larvae presence in higher three concentration $10^{7}, 10^{8}$ and $10^{9}$ conidia $\mathrm{m}^{-1}$, no significance in mortality between both larvae in Bb-Am5, Bio-power and Bio-magic isolate.

Table (4): Analysis of variance of the effect of host species and entomopathogenic fungi isolates and EPF concentration on the corrected cumulative mortality percentage of the host larvae.

\begin{tabular}{|l|c|c|c|c|c|}
\hline Source of variation & df & SS & MS & F & P-value \\
\hline Host species (A) & 1 & 2773.89 & 2773.89 & 84.30 & $<0.0001$ \\
\hline EPF isolates (B) & 4 & 4039.21 & 1009.80 & 30.69 & $<0.0001$ \\
\hline EPFconcentration (C) & 3 & 21535.01 & 7178.34 & 218.15 & $<0.0001$ \\
\hline ( A ) X ( B ) & 4 & 986.14 & 246.53 & 7.49 & $<0.0001$ \\
\hline ( A ) X ( C) & 3 & 88.55 & 29.52 & .90 & 0.4465 \\
\hline ( B ) X ( C ) & 12 & 712 & 59.41 & 1.81 & 0.0611 \\
\hline ( A ) X ( B ) X ( C ) & 12 & 77.14 & 6.44 & 0.20 & 0.998 \\
\hline Error & 80 & 2632 & 32.90 & & \\
\hline
\end{tabular}

a df, degree of freedom; SS, sum of squares; MS, mean square; *highly significant $(P<0.05)$.

Data in Table (3) show the $\mathrm{LC}_{50}$ value of selected native and exotic EPF isolates and revealed that $G$. mellonella was more susceptible that $S$. littoralis for all tested isolates. In addition, the native isolate Bb-Mo12 and BbBo10 were higher virulence in compare with exotic isolates against $G$. mellonella larvae with $\mathrm{LC}_{50} 1.3 \times 10^{6}$ and $5.0 \times 10^{6}$ conidia $\mathrm{ml}^{-1}$ respectively. while the lower virulent isolates was Bio-power with $1.1 \times 10^{8}$ and $2.6 \times 10^{8}$ conidia $\mathrm{ml}^{-1}$ for $\mathrm{G}$. mellonella and $\mathrm{S}$. littoralis larvae respectively.

The analysis of variance (ANOVA) results summarized in Table (4) show highly significant effect of host larvae species $(P<0.0001)$ and EPF isolates $(P<0.0001)$ in addition to their interaction which mean that the effect of host larvae species depend on the EPF isolate and vice versa. Also data show highly significant effect of EPF concentration $(P<0.0001)$ while the interaction of EPF concentration with Host species or EPF isolate or both were not significant. 


\section{DISCUSSION}

The occurrence of $B$. bassiana and $M$. anisopliae in Egypt, confirms their reported widespread distribution in soils worldwide (Vänninen 1996; Bidochka et al. 1998) in addition to, they were previously isolated from Egypt by El-Husseini et al., 2003 who isolate three species of EPF B. bassiana, $M$. anisopliae and Pacilomyces lilaceous. From three governorate Giza, Dakahlya and Kafr El-shikh using the insect bait technique they found the recovery rate of EPF from collected soil sample was $1.07 \%$ with total 16 isolates. In other work from Egypt Sabry et al., 2011 isolate B. bassiana and M. anisopliae from soil sample collected from El-Behira Governorate.

The entomopathogenic fungi, used in the present work caused considerable mortality effects against the tested larval of $S$. littoralis and $G$ mellonella which agree with Ashraf and El-Katatny (2007) who stated the competency of the entomopathogenic fungi, B. bassiana, A. flavus Link and $T$. harzianum to be used in the biocontrol regime against the Egyptian cotton leaf worm, S. littoralis. In addition several workers report a result agree which our finding such Zayed, 2003, who test the pathogenicity of two native isolate of $B$. bassiana and found virulence variation in the $L_{50}$ and $L_{50}$ toward $G$. mellonella larvae

The present study show variability in the pathogenicity of tested fungal isolates towards $G$. mellonella and $S$. littoralis larvae. This variation among isolates could be related to, the attachment way of spore into insect cuticle, the speed of germination of the conidia of each isolate, the variation between isolate in the activities of extracellular hydrolytic enzymes or variation in the amount produce of all or some of the infection catalyzing enzymes (Momein, 2010). Perkul and Grula, 1979 on a study of comparing between the development of high and low virulent isolate of $B$. bassiana recognize the difference in the growing manner of the fungal isolates over the cuticle surface of the host which indicate the effect of growing manner in the isolate virulence toward a host insect in addition

The variation in pathogenicity of an isolate toward different insect host may be due to the variation in host immune system and the recognition ability (Chandler et. al., 1993), extracellular subtilisin-like chymoelastase designated protease and other components are considered one of the main pathogenicity determinants for entomopathogenic fungi (St. Ledger et al. 1987; Castillo et al. 2000). The potential activity of entomopathogenic fungal isolate may probably be due to the combination of enzymatic, volatile and non-volatile antibiotic activities, which are thought to be closely related in virulence factors for some entomopathogenic fungi and play a role in their mycoinsectisides against the target insects (Fan et al. 2007).

From the obtaining results, it could be concluded that the soil sample contain a variety of entomopathogenic fungi which differ in their virulence toward different insect host and concentration dependence. A promising native isolates in the control of insect pest could be compete the commercial product of entomopathogenic fungi in their virulence and pathogenicity. 


\section{REFERENCES}

Abbott, W. S. 1925. A method of computing the effectiveness of an Insecticide. Journal of Economic Entomology, 18:265-267.

Ashraf, M. Ahmed and M. El-Katatny. (2007). entomopathogenic fungi as biopesticides against the Egyptian cotton leaf worm, spodoptera littoralis: between biocontrol- promise and immune limitation. j. Egypt. soc. toxicol 37(1) : 39-51.

Bidochka MJ, Kasperski JE, Wild GAM. 1998. Occurrence of the entomopathogenic fungi Metarhizium anisopliae and Beauveria bassiana in soils from temperate and nearnorthern habitats. Canadian Journal of Botany Revue Canadienne De Botanique 76: 1198- 1204.

Bishara, I., 1954. The cotton worm, Prodenia lituro F., in Egypt Soc. Ent Egypt Bull., 18: 288-420.

El-Defrawi ME, Tappozada A, Mansour N and Zeid M, 1964.Toxicological studies on the Egyptian cotton leafworm Prodenia litura L. Susceptibility of different larval instars of Prodenia to insecticides. $J$ Econ Entomol 57:591-593.

El-Husseini, M.M.; Shahira, S. Marie; A.M. Amal; A. El-Zoghby; Sahar S. Ali, Naglaa, A.M. Omar; E.A. Agamy; H.E. Abou Bakr; M.S. Nada; Sherin Tamer; Hannah, M. Kamal and A.M. Ibrahim, 2004. Isolation, Production and use of entomopathogenic fungi for controlling the sugar beet insect pests in Egypt. Egypt. J. Biol. Pest Control. 14(1): 265-275.

El-Husseini, M.M.;Mesbah,A.H.; El-Zoghby A. and Agamy, E.A. 2003. Isolation propagation and application of the entomopathogenic fungi for controlling noctuid and cassidid pests in sugar beet. Egyptian journal of biological pest control, 13(1\&2).95-100

Castillo M-A, Moya P, Herna'ndez E, Yu'fera EP. 2000. Susceptibility of Ceratitis capitata wiedemann (Diptera: Tephritidae) to entomopathogenic fungi and their extracts. Biol Cont. 19:274-282.

Chandler, D., Heale, J. K., and Gillespie, A. T., 1993. Competitive interaction between strains of Verticillium lecanii on two hosts. Annals of Applied Biology, 122: 435-440.

Chandel, Y. S., Sharma S. and Verma, K. S. 2003. Comparative biology of the greater wax moth, Galleria mellonella L., and lesser wax moth, Achoria grisella. Forest Pest Management and economic zoology 11: 69-74.

Gabarty, A., Salem, H. M., Fouda, M. A., Abass, A. and Ibrahim, A. A. 2014. Pathogenicity induced by the entomopathogenic fungi Beauveria bassiana and Metarhizium anisopliae in Agrotis ipsilon (Hufn.). J. Radiat. Res. and Appl. Sci., 7(1): 95 -100.

Gerhardson, B 2002. Biological substitutes for pesticides. Trends Biotechnology 20:338-343. 
Hajek, A.E., Humber, R.A. and Griggs, M.H., 1990. Decline in Virulence of Entomophaga maimaiga (Zygomycetes: Entomophtorales) with repeated in vitro subculture. Journal of Invertebrate Pathology 56: 91-97.

Hall, R.A. and Papierok, B., 1982. Fungi as biological control agents of arthropods of agricultural and medical importance. Parasitology, 84, 205-240.

Humber, R.A., 1997. Fungi: Identification. In Manual of Techniques in Insect Pathology (L.A. Lacey, ed.), pp. 153-185. Academic Press: London.

Hussein, K.A., Mohamed A. A., Ahmed Y., Saad S. E and Jin Ho Joo, 2012. Pathogenicity of Beauveria bassiana and Metarhizium anisopliae against Galleria mellonella. Phytoparasitica, 40:117-126

Jackman, J. A. and Drees, B. M. 1998. A field guide to Texas insects, Gulf Publishing Company, houston, Texas.

Lin, H. P., X. J. Yang, Y. B. Gao and S. G. Li. 2007. Pathogenicity of several fungal species on Spodoptera litura. Chinse J. Appl. Ecol., 18(4): 937-940.

McCoy, C.W., Samson, R.A. and Boucias, D.G. 1988. Entomogenous fungi. In C.R.C. Handbook of Natural Pesticides. Volume V: Microbial Insecticides, Part A. (Ignoffo, C.M., ed.). C.R.C. Press Inc., Florida, pp. 151-236.

Momein H. El-Katatny , 2010. Virulence potential of some fungal isolates and their control-promise against the Egyptian cotton leaf worm, Spodoptera littoralis, Archives Of Phytopathology And Plant Protection, 43:4, 332-356

Moore, D. and Prior, C. 1993. The potential of mycoinsecticides. Biocontrol News and Information, 14, 31-40.

Moussa, M.A., M.A. Zaher and F. Kotby, 1960. Abnndance of the cotton leafworm Prodenia littura (F.), their effect on biology. Bull. Soc. Ent Egypt, 44: 241-251.

PDBC.2007.Traning on Entomopathogenic nematode for insect pest control. Training manual for "Hands-on Training on Entomopathogenic nematode" $20^{\text {th }}$ march to $29^{\text {th }}$ march 2007, Project directorate of biological control, Bangalore, India

Pekrul, S., and Grula, E. A. 1979. Mode of infection of the corn earworm Heliothis zea by Beauveria bassiana as revealed by scanning electron microscopy. Journal of Invertebrate Pathology, 34: 238-247.

Purwar, J. P. and G. C. Sachan. 2005. Biotoxicity of Beauveria bassiana and Metarhizium anisopliae against Spodoptera litura and Spilarctia oblique. Ann. PI. Protec. Sci., 13(2): 360-364.

Sabry,K.H.; Abdel-Raheem, M,A and El-Fatih M.M., 2011. Efficacy of the entomopathogenic fungi ; Beauvaria bassiana and Metarizium anisopliae on some insect pests under laboratory conditions.Egyptian journal of biological pest control.21(1),33-38

Samson RA, Evans HC, Latge' JP, 1988. Atlas of entomopathogenic fungi. Springer, Berlin, Germany

SAS Institute Inc. 2004. SAS/ETS® 9.1 User's Guide. Cary, NC 
Shairra S.A. and Gehan M.N. 2014, Efficacy of Entomopathogenic Nematodes and Fungi as Biological Control Agents against the Cotton Leaf Worm, Spodoptera littoralis (Boisd.) (Lepidoptera: Noctuidae). Egyptian Journal of Biological Pest Control, 24(1), 247253

St. Ledger RJ, Charney AK, Cooper RM. 1987. Distribution of chymoelastases and trypsin-like enzymes in five species of entomopathogenic deuteromycetes. Arch Biochem Biophys. 123:122-31.

Spangler, H. G. 1989. The role of ultrasound and pheromone communication of greater and lesser wax moths. Bee World 70 (3): 132-133.

Thackar, J. R. M. 2002. An introduction to arthropod pest control. Cambridge University Press, The Edinburg Building Cambridge CB2 2RU, UK, pp. 144.

Tubiello, F.N., J.A. Amthor, K. Boote, M. Donatelli, W.E. Easterling, G. Fisher, R. Gifford, M. Howden, J. Reilly And C. Rosenzweig, 2007, Crop response to elevated $\mathrm{CO}_{2}$ and world food supply. Eur. J. Agron., 26, 215-223.

Vänninen I. 1996. Distribution and occurrence of four entomopathogenic fungi in Finland: Effect of geographical location, habitat type and soil type. Mycological Research 100: 93- 101.

Willcocks, F. C. and S. Bahgat, 1937. The insect ad related pests of Egypt Vol. 1, Part 2, Insect and mites injurious to the cotton plant. Royal Agric. Soc. Entomological Section, Cairo, Egypt.

Zayed, A. 2003. Pathogenecity of two Beauveria bassiana indigenous isolates towards the greater wax moth Galleria Mellonella I. larvae in Egypt. Efflatounia, 3: 10-14

Zimmermann, G. 1986. The Galleria bait method for detection of entomopathogenic fungi in soil. J. Appl. Entomol. 102: 213-215. 
الكفاعة الأبادية لعزلا محلية من الفطريـات الممرضة للحشرات على يرقات ديدان الشمع ودودة ورق القطن

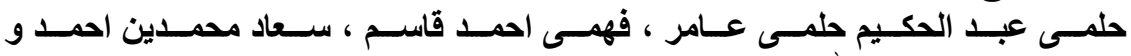

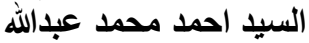
قسم كيماء وتقنية المبيدات, كلية الزراعة, جامعة الأسكندرية

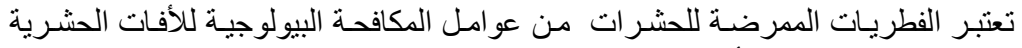

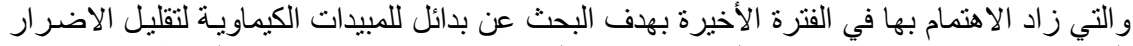

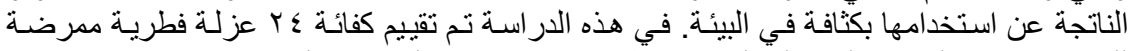

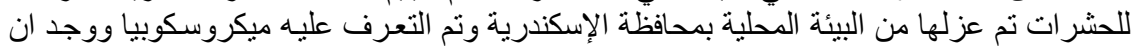

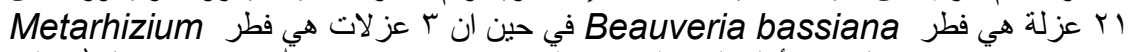

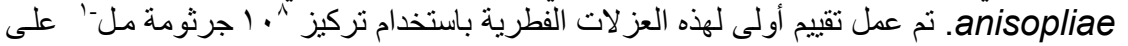

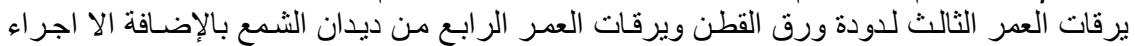

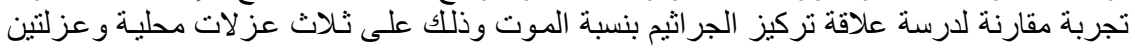

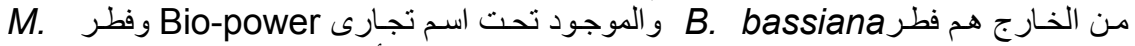
anisopliae

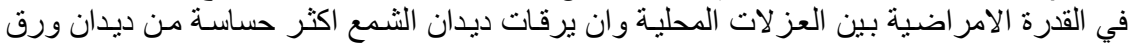

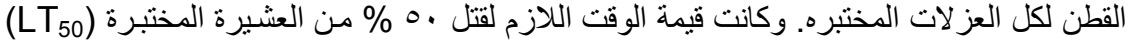

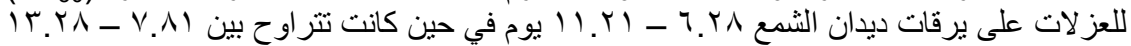

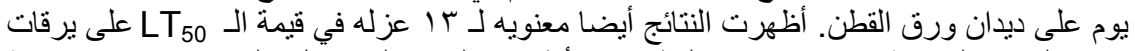

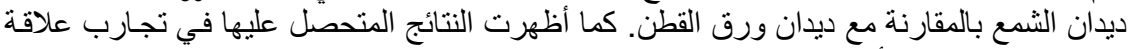

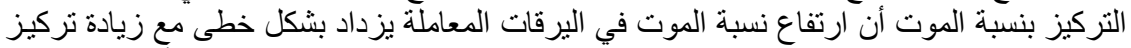

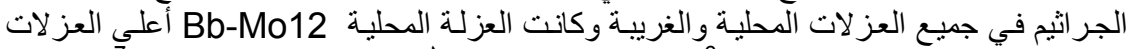
كفائه بقيمة

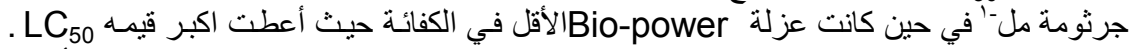

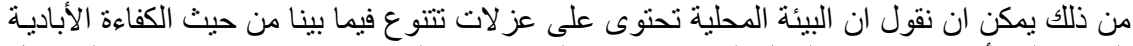

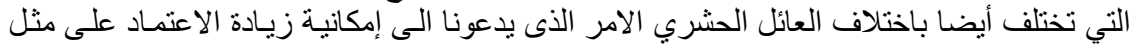

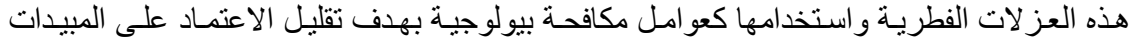
الكيماوية في عملية مكافحة الافات الحشرية. 